Many planners have felt more anxious and burdened and the clinicians have felt correspondingly less oppressed and perhaps this is allowing both groups more opportunity for reflection on the future pattern of service. Since there is now more contact with reality it may be possible for a dialogue to develop, although it is doubtful whether it will lead to substantive changes in the plans.

It is difficult to say what the future holds. At the moment it looks as though there are new developments on the horizon, but the acid test is whether they will be sustained. The reality is that for all we have gone through only a small number of patients, by no means the most disabled, have left the hospital. Furthermore, as the diffculties and realities are striking home, the prospect of transinstitutionalisation is becoming more and more real. While initially there was an anxiety that the long-stay wards would merely be re-created in the community, another more formal type of institutionalisation is becoming apparent. As the implementation of community care becomes more problematic and expensive, small hospitals are being earmarked for combined use for mental health, mental handicap and psychogeriatric services. The old mental hospital philosophy is alive, but is likely to appear in a new suit of clothing, without the grandeur or the grounds of the existing Victorian asylums.

In 1983 we were given the answer "The hospital will close". This was rather like the situation in the Hitch Hiker's
Guide to the Galaxy where the answer was 42 . The problem is what is the question?

\section{ACKNOWLEDGEMENTS}

I would like to thank Professor Kathleen Jones and Hemda Garelick for their helpful comments.

\section{REFERENCES}

${ }^{1}$ JAQUES, E. (1955) Social systems as a defence against persecutory and depressive anxiety. In New Directions in Psychoanalysis. London: Tavistock.

${ }^{2}$ Menzies, Isobel, E. P. (1960) A case study in the functioning of social systems as a defence against anxiety. Human Relations, 13, 95-121.

${ }^{3}$ JoNES, K. (1955) Law, Lunacy and Conscience 1744-1845. London: Routledge \& Kegan Paul.

${ }^{4}$ SCuli, ANDrew T. (1979) Museums of Madness. London: Allen Lane.

${ }^{5}$ Goffman, E. (1961) Asylums. London: Anchor Books, Doubleday \& Co. Reprinted as a Pelican Book (1968).

6JONES, K. (1985) After Hospital: A Study of Long-Term Psychiatric Patients in York. University of York.

7__ \& Poletr1, A. (1985) Understanding the Italian experience. British Journal of Psychiatry, 146, 341-347.

8 _ \& _ (1986) The Italian experience reconsidered. British Journal of Psychiatry, 148, 144-150.

${ }^{9}$ Goffman, E. (1982) In Psycho Politics (P. Sedgwick). London: Pluto Press.

${ }^{10}$ Segal, H. (1973) Manic defences. In Introduction to the Work of Melanie Klein. London: Hogarth and the Institute of Psychoanalysis.

\title{
The World Society of Victimology (WSV)
}

The WSV is a non profit-making, non-governmental organisation. Its members, brought together from around the world by their mutual concern for victims, include victim assistance practitioners, lawyers, social workers, physicians, professors and students. Its purposes are to promote research about victims, to assist victims and advocate their interests throughout the world; to encourage interdisciplinary and comparative research in victimology; and to advance the co-operation of international, regional, and local agencies, groups and individuals concerned with the problems of victims.

The WSV sponsors symposia, workshops and seminars, including an International Symposium on Victimology every three years. It also sponsors the International Review of Victimology to encourage the exchange of theories and research and to foster the discussion of victim service projects. The WSV Newsletter keeps the membership informed of major activities relating to victims and an International Bibliography has been established to facilitate access to the growing literature on victims.

Those wishing to become members should write to Prof. Dr. Hans Joachim Schneider, Director, Department of Criminology, University of Westphalia, 24/25 Bispinghoff, D-4400 Muenster/Westphalia, Federal Republic of Germany.

\section{Rehabilitation Centre for Torture Victims (RCT)}

The RCT is a private foundation based in Denmark, financed by government funds and private donations. Its aims are to run a centre for the rehabilitation of people who have been subjected to torture and their families; to instruct health personnel in the examination and treatment of those who have been subjected to torture; to engage in research on torture and on the nature and extent of its consequences for the purposes of treatment and eventual abolition; and to set up an international documentation centre for registration of facts about torture and its effects. Further information: RCT, Juliane Maries Vej 34, DK-2100 Copenhagen Ø, Denmark. 